\title{
I Won't Come Back To Earth
}

\author{
Margaret Christakos
}

\section{Je ne reviendrai pas sur terre}

I was colonized by internalized codes about duty (Nov22)

Quand j'étais jeune, on m'appellait une rêveuse, mes divagations "romantiques,"dévalorisées ainsi, tout ceci par des hommes qui s'estimaient au-dessus de toute rêverie et qui déployaient leur pouvoir patriarcal pour delégitimiser les mots d'une jeune fille. Comment se fait-il qu'au vingtième siècle la rêverie d'une femme - l'imagination pure - devient une idylle romantique quand la rêverie a toujours été la prérogative du poète masculin héroïque? L'écrivaine féministe interroge le discours littéraire du Romantisme qui établie le sublime comme un territoire à être pris dans une quête glorieuse d'un héro masculin inspiré par les souvenirs et les fantasmes d'une mère-muse. Elle se penche sur la problématique du sujet unaire, univoque, la voix qui parle et affirme sa domination sur l'objet du regard, c'est-à-dire sur la muse. Selon le discours poétique à l'époque romantique, le poète se construit en usurpant l'expérience et le corps de sa muse pour son texte. Cependant, quand il vient le tour de la muse pour se mettre à exercer ce même pouvoir, elle se greffe à elle-même, le féminin muét, commodifié et nommé de l'extérieur. La jeune étudiante de la création littéraire se forme selon le discours dominant en poète et en muse simultanément et perdre sa langue dans la contradiction. La jeune poète devenue féministe essaie d'écouter ses rêves, apprends à refuser la quête romantique et de se libérer des codes quil'ont impérialisée.

When I was a young girl I was called a daydreamer, and so my ramblings were often characterized and discredited as "romantic" by those who considered themselves impervious to this quirky ilk of vision, often, that is, by men. Older men who censored the dreaming of a young girl. How did they do this? How did I know they were meaning to do this to me, to my dreaming? Mostly, I believe I didn't 
know the reason behind their intervention, only the wallop it packed. I would contend now that the men didn't know either. Somehow I was gendered by my culture to be the dreamer, and then to be the one who is stigmatized for dreaming impossible relationships, ethereal ones, made of gossamer, girlish dreams; and the male onus was to never dream, or to promulgate a dreaming which was preparatory, like the pep talk a coach gives his prize boxer before the dreamt-of knock-out. To knock consciousness from his opponent's skull, this was the patriarch's dream, assigned by an ideology that holds supremacy of the few as an essential guarantor of existing power hierarchies.

In this context I mean the "prize" to be self-possession, the condition of operability and ownership of oneself as a subject in a given text, a subject parenthetically here in the text of patriarchy. In this complicit condition, the role of censor, of prize fighter for the territory of the ring of power, the polis, is open game for both sexes. We knock each other's dreams flat no matter our biological category. The patriarchal parent, regardless of sex, can be the referee castigating "young" or illegitimate dreams that challenge the arbitrary limits delineating the polis' playing surface. The point of the contest is to systematically beat unconscious at least half of any pairing. This is one dream, the western patriarchal dream which fuels its myth of self-possession with each beating.

The ontology of the playing surface is that it exists only for the declaration of a finite economy of subjectivity between subjects who retain self-possession, and subjects who have it forcibly wrested from them.

Or so I am arguing, in order to possess you, here in this text, as my patron. Or am I arguing? Do I wish for your patronage? And why might I, what relative power might I need, and why?

As a feminist writer, I consider my dreaming to overrun the boundaries of the playing surface ascribed by both the conventions of Romanticist poetics, and the patriarchal mythos of supremacism. But how did my female dreaming - "flights of fancy" - in the mid-twentieth-century come to be the repository of romantic idyll, when the roots of such privilege have belonged squarely to the heroic male poet? Answering this question involves a multiple interrogation of historical shifts in the textual and cultural relationships between world and word, between gender and sensibility, between embodied 
subjectivity and the subjected body. Of course these intersecting discourses can be made to go on in the specialized terrain of academia, of literary theory, and of sexual difference, and represent an exclusionary perspective on what constitutes a playing surface at all. Because I know I feel drawn to this form of exclusion, and want to challenge its effect, because I now believe writing to be about my own and others' dreaming, I will work in this text to throw open the doors of the stadium, to dismantle the admission policy of previous managements, to stop myself short of needing your patronage while still inscribing compassion for you as my reader.

\begin{abstract}
$* * *$
To be colonized is to be rendered insensitive. To have those parts necessary to sustain life numbed. And this is in some cases...perceived as privilege. The test of a colonized person is to walk through a shantytown in Kingston and not bat an eye. Michelle Cliff ${ }^{1}$
\end{abstract}

I want to test myself and us: is it to awaken from a state of colonization by patriarchy, to become a feminist writer, reader, and subject? I'm using this conceit of waking, of coming back to consciousness as if from a weighty sleep or enforced coma, because as a metaphor it has literary resonance, and because I feel it earnestly; being involved in an ongoing process of interrogating social structures has felt to me like a profound sensitization in my skin and in my ethic, it has felt like the sprouting of ancillary antennae, like muscularized logic, like resistance, and it has felt like ripping, like emergency, in the sense of a rising up of myself from an obscure or inferior position through a problematized surface, to a location that redresses the binary construct "Above the reality line (as men define it)/ the female body is left behind." 2

Some thing peculiar has claimed itself here, and I have let it (who's writing this, anyhow?): that, ideologically to vanquish ["to gain mastery over (an emotion, passion, or temptation"] is a masculine reponse to the feminine stimulus or project dreaming. In Wordsworth's day this would have been hard to contend, since dreaming was the professional province of boy-poets, and the Sublime was territorialized was a glorious male quest. Also, the fiction of the inner voice of pure tonguespeaking (Nov 29) was a ceremony of freedom conferred only upon the 
inspired male poet (while a woman similarly fluent would have been known to speak in evil deliriously tongued, flailing semaphoric lips in a vacuum since no one would hear her; it would be like a silent movie, where somehow her voice has been leeched whole from her body, and the gestures she makes are spasms, fragments, unintelligible because of the way the structures of language make her mute.) So I want to place him clearly on a field, this nineteenth-century "modern" poetic visionary, scientist, capitalist. (" $\mathrm{T}]$ he Romantic poet is able to retain his masculine identity as romance quester, for he also identifies subliminally with two new masculine roles [...] the scientist and the capitalist." 3 I want to see his eyeglass raised in contiguous space which revolves about him, his senses, and glean what the texture of the world is once it has passed through his lens. I belive he is not colonized by internalized codes about duty, at the very least not by the same ones possessing me; and as I feel his eyes on me, on my bent-over body as I wash laundry on the rocks by the river, as I go about my assigned duty, do you see this, the rocks, his distant consumption of me, how he subjects me there, exacts me, do you see the various nouns soar across the field torn from the wet clothes - the wet labia, the nipple, the tired cuticles - all these morsels for his appetite, destined for a universal resurfacing? He chews me. And I reappear in the mythos of femininity as a particularly emblazoned washerwoman, who may be punished or sainted according to the given allegory, who is meant to nurse his creative thrust with my female blood, my milk, my feeling.

"In moving from an "Age of Reason" to an "Age of Feeling" male writers drew on memories and fantasies of identification with the mother in order to colonize the conventionally feminine domain of sensibility," 4 and relied on imagery of "the male child's absorption of his mother's sympathetic faculty" - nursing, imbibing milk, blood, tears," 5 "figuratively cannibalizing" 6 her in many incarnations, allowing that "the figure of nursing can be rarefied or transcendentalized [as] lover or sister," 7 all in all, musing her.

Of course, I' $m$ the writer who has defined the terms of invention of the washerwoman above but the ideology that informs how I know how to invent her flesh to serve a rhetorical facticity is inherited from my culture and logical conventions which privilege the space of this argument. For the construction of the Romantic muse depends on her "feminine" willingness to serve the [male] poet's ordering of mythi- 
cized way-it-is-ness. She exists as the projection of his text-to-be, the body through which he will come to language: she will lip-synch "his words into her labia/ cunting her silence/ siren,/ inaudible." ${ }^{8}$ In a recent essay, Erin Mouré has theorized what she calls this "poetry of the observer" as a polarization of "the poetic voice observing and commenting on an external world," in a relationship where "certain destructions become possible." The deeply sexist, racist, classist, othering stance of Western Poetry, its machismo, has everything to do with the poet's assumption of [his] subject matter, the belief of [his] own centrality, and the privilege of [his] univocal image-nation. This is the self-articulation of the poet prize fighter-I'm gonna cream youwhose discipline it is to project a certainty of "the dominance of the voice-that-speaks over that which it observes." Mouré goes on to write:

...it seems the image often represses more than it conveys - the expression of one 'sight' suppresses contradictory or anti-rhythmic others. In this, to me, is the limitation of the lyric form, and the triumph of a social order that thrives by exclusion rather than inclusion. ${ }^{9}$

By this suppressive design, then, my washerwoman performs the double-bind of the Romantic poet's place near the river when female: in order to exist at all she/I learned to self-cannibalize our lateral naming of reality into the burgeoning (vertical) surf of poetic metaphor. The duplicit duty I imbibed as a young white female student of Canadian Creative Writing was to become both poet and muse, and to express through my body into text both conventions simultaneously in fullblown transparency. Because the Romantic construction of the poet is premised on the digestibility of [his] muse, of usurping her body and experience for his text, when the muse herself performs this same imperialism she drafts herself into the tongue-tied essentializing of herself as feminine, thus mute, as objectified for consumption, as named from outside, as amnesiac by design, as self-betraying. The double-bind is familiar treachery, is an extension of the inculcation girls experience to unname our own dreaming at the same time as we are imbibed into a naming from beyond. And I would press my gaze to the aquarium glass and name this split, where the naming function of language was transposed to serve what is sustained by the vertical order to be unknown, deferrred, repressed, the dilemma of trying to speak underwater. Impossible to imagine what the surface of an 
ocean looks like while the poet is submerged under its hermetic skin, never having leaked through it to see it from above, never ever having spoken without unconscious but skilfully lip-synchronized manoeuvres to prevent death by drowning. This is to be colonized by the mutiplicit duties of femininity, to please, to be pleasing, to inspire patriarchal possession of the world (he who names it, owns it) while disavowing one's self-possession as a girl dreaming, one's own selfnaming as a woman writing. Modern Romanticists abound (please read this poem's scripting):

Suzanne takes you down

to her place near the river, you can hear the boats go by you can stay the night beside her.

And you know that she's half-crazy but that's why you want to be there and she feeds you tea and oranges that come all the way from China. Just when you mean to tell her that you have no gifts to give her, she gets you on her wave-length and she lets the river answer that you've always been her lover.

And you want to travel with her you want to travel blind and you know that she can trust you because you've touched her perfect body with your mind. ${ }^{10}$

"The dominance of the voice-that-speaks over that which it observes," in the way of the capitalist, the imperialist, the xenophobe, I find hard to impugn in Cohen's lyric when its rapturous surface is held up against the sociohistorical diorama of destructive and objective masculinity. Cohen's poem seems at least to be about love, about the sensual world, in its feminine aspect. It's hard to hear anything brutish in his tunefulness. And I didn't want to, still don't I find; I want to be moved by his passion, want my own to be re-invented on each reading! But it is the arrogance of the design that lets me un-write my readerly innocence. When I name the assumptions the poem makes in aesthetic service arrogance, and not love, I begin to long for 
Suzanne's liberation from Cohen's ideological rigor mortis. And also for the memoirs of those Chinese imports to write themselves, thank you. And the perfect body of Woman to rise up in a self-inscribed pock-decorated burlesque.

What fuels this revulsion in me? Recent honesty, I think. Knowing I cannot possibly be honoured in Cohen's version of beauty, and still wake up in the morning. And that the unitary perpective of this poetic imagination is obsolete both in the socio-political space of feminist theory and practice, and in my writing body.

Now if we agree that a woman's memory is a memory inscribed in a marked body, if we agree that this memory is closely linked to a series of intimidations and repeated constraints in patriarchal churning in her will inevitably trace an explanatory map of the wounds and scars scattered over her body, as well as a map of the sudden rushes of joy that impassion thinking (Nicole Brossard). ${ }^{11}$

This moment of honesty is one of revulsion, of standing back appalled at either the stark inequality of one's psychosocial condition, or at one's own complete absence in the world, and it has been expressed by a continuum of writing by women for centuries. A classic example is Kate Chopin's The Awakening, published in 1899. In an almost pedagogical tone, Chopin delineates her heroine's critical moment:

In short, Mrs Pontellier was beginning to realize her position in the universe as a human being, and to recognize her relations as an individual to the world within and about her. This may seem like a ponderous weight of wisdom to descend upon the soul of a young woman of twenty-eight - perhaps more wisdom than the Holy Ghost is unsually pleased to vouchsafe to any woman.

But the beginings of things, of a world especially, is necessarily vague, tangled, chaotic, and exceedingly disturbing. How few of us ever emerge from such beginning! How many souls perish in its tumult!... ${ }^{12}$

And then, this curious non-sequitur:

...The voice of the sea is seductive; never ceasing, whispering, clamoring, murmuring, inviting the soul to wander for a spell in abysses of solitude; to lose itself in mazes of inward contemplation. 


\section{Won't Come Back To Earth · 47}

The voice of the sea speaks to the soul. The touch of the sea is sensuous, enfolding the body in its soft, close embrace. ${ }^{13}$

Chopin writes an example of Romanticism's profound double message for the female writer; for at the moment her heroine stands on the brink of political transgressivity as a radical subject in women's fiction of the day, Chopin's Mrs Pontellier is fixed steadfastly in to the confines of the Romantic imagination, warned of erasure by the dramatic potency of the poetic image. The anthropomorphized water becomes a metaphor of the unknown risk for women of self-knowledge; that to experience consciousness would be akin to falling into uncharted space, to be poised at the boundary of insanity, disorder, profuse sensuality. So that Mrs Pontellier's fate has indeed been foreshadowed. Just preceding the novel's ambiguous suicide scene in which she is at the very least written out of textual possibility, the earlier passage is deliberately remobilized:

How strange and awful it seemed to stand naked under the sky! how delicious! She felt like some new-born creature, opening its eyes in a familiar world that it had never known.

The foamy wavelets curled up to her white feet, and coiled like serpents about her ankles. She walked out. The water was chill, but she walked on. The water was deep, but she lifted her white body and reached out with a long, sweeping stroke. The touch of the sea is sensuous, enfolding the body in its soft, close embrace. ${ }^{14}$

The critical moment in this rendition is allowed to exist only in a schizophrenia of, on the one hand, emphatic self-awareness in the heroine and the text-respondent, and a simultaneous absorption of this energy into the text's recuperative aesthetic project, that is: to seal off the radical possibility of a woman's trajectory to self-possession within the amorphous textual aphasia of Romanticism. Reading this outcome I first feel Chopin's writerly vision was co-opted by her own internalized codes about duty as a woman and a novelist. I feel capitulation and silence as Mrs Pontellier loses her bearings in the waves. Or do I collude to silence her by my failure to envision that, like many women experimenting with resistance, Chopin was consciously writing the death not of a woman for transgression, but of the patriarchal mother, as Nicole Brossard's feminist text These Our Mothers/ (S)our Mothers/ Theseourmothers/ The Sea Our Mother/ Or: The Disintegrating 
to define himself, if he is male, take himself seriously because he and his public assumes his significance within the dominant order. Only in the fullness of the membership can the fullness of his rebellion unfold. For women, on the other hand, rebellious pursuit is potentially catastrophic. ${ }^{24}$

But what exactly constitutes "rebellious pursuit" on the part of women? To write in self-possession is highly discouraged; where the Romantic male poet's legacy and privilege has been self-absorption at the expense of his cannibalized female muse, when women write personally revelatory poetry we have been discredited and dismissed as "confessional," "indulgent," and obsessed with our wombs. At some point we wake up, wheel about, and find ourselves flat on the floor, we remember this moment, it hits us, we hit it, its mask corrupts:

April 3 dream last night confused, but vivid image of being longhaired, early teens, dark strands curtaining my ears, \& I'm on a field, on grass, \& suddenly from nowhere I can see there is a flexing from the side or from the above I'm being hit by a slab of wood, I see it coming in slow motion, it connects squarely along the ridge of my temple, the side of my head, splitting, vicious with a loud crashing, \& pain, and then I swoop down, crumple, knocked unconscious... when I awaken I reach to other women for solidarity and comfort.

This is one of my own dreams, as an adult woman. I contend for myself that it marks the sentient moment in my socialization when I took the glove in the face, then the chalky platform of the hard floor in the face, took my subjectivity in like clean laundry for a hope chest. When I was quite literally knocked out of sense.

For many women trying to write, being knocked back into sentience is necessary and parallel trauma to the adolescent knockout effect:

RITUAL WITH TREMBLING

...The woman who writes, who wants to write, hears the voice, sees the inner landscape, knows the hour and the place of the event where something in her life began, stopped; but for all this still remains unspeakable. Then the image comes back, insists, strikes the temple hard, crosses the body like a bolt of lightning. Then the body begins to tremble... ${ }^{25}$ 
I now can excavate the loss of self in my textual archives. Write though I did, for years sentences like the next would write themselves in my journal, trying to negotiate codes about duty and beauty, inspiration and performance, self-terrorizing inquiry:

Dec 2 The parts disqualify, so a fictive whole sits on the dining room table like a bowl of plastic fruit. Why? Because decoration is crucial to theatre.

This could be hummed to Cohen's acoustic version of "Suzanne Takes You Down To The River." It seems so ageless, quite holy even. Note for Poem without a girlhood, no. 301. To be cross-referenced as Note for Poem without a sympathetic nervous system, AAA. "self erasure/ as a safety measure. / / a measure of/ self erased.// how can we/ measure the self/ erased?" ${ }^{26}$ I long now to article my early texts, to lift them out of their drowsy self-refusals. And I learn from feminist writers, as in Erin Mouré's recent book Furious ${ }^{27}$ that Cohen's Romantic melodiousness and arrogances can indeed be subverted, and ought to be; and that the feminist poet can inscribe anew a critical ideology where self-possession becomes positively constructed as a political condition, where we dream, refusing both co-option of our memory, and any vestige of participation in cannibalizing the real or metaphoric future.

To the earlier question, what makes for rebellion in women's writing: In the broadest sense I would answer to speak among women is rebellious. To remember is treason, and generally disarms the prizefighter and his coach together. And as Brossard writes, "...language makes women nonexistent, obliging us to perform rituals of presence which exhaust the most vulnerable, while electrifying the most audacious among us. Thus to write I am a woman is full of consequences." 28

The gesture of a woman writing, my own condition as a writer, is to be suffused with the struggle to remember. I cannot cast my desire like a fishing line into the real or the literarily entrenched fiction of dominant patriarchal experience and "imbibe" an assumption of my logos. I have to stab up through the seal which constructs my amnesia of girlhood, for as I've written I believe amnesia to be intended for women as a patriarchal rite of passage; and this action is an emergency through naturalized or seamless language to finding reorganized ontological relevancies between my personal memories, an ever-expanding women's imaginary through history, and the semantics of fear that 
have textured all forms of my speech acts...Do you want me to be? For my own and women's remembering, the admission of consistent notknowing and unsafety as daydreams were steadfastly irrupted re-engages the nervous system, and the sudden and apocalyptic movements where pieces of the body - the wet labia, the nipple, the tired cuticles - fly back and singe themselves into the sympathetic body bristle at the cranium. I awake morning after morning with reports on my tongue:

Dec 14 dream of a daughter saying to her mother "you have no idea how hard it is to love women in this cuture."

Jan 7 I had a strange doubled sense waking the other morning, that my political consciousness was somehow still floating above my skin

Jan 16 dream of jumping up into air reaching height so exciting moving my arms as if running both legs ahead at once to hold me there UP \& slowly hovering then descending the attempt to stay UP its pleasurability jumping 3 or 4 times like this, getting higher each time staying up a little longer...

Jan 18 last night my dream of being at the lake the light silvery at night on the wintertime beach older brother arthur there me young what, $13 / 14 \&$ him not daring to come in the water then my strides into it up to waist cold but almost body temp going further submerging my whole body into the inky cool transparent realm under it feeling protected familiar \& good then a wave coming, pushing forcing me to break the surface propelling me above the waterline to flat momentarily above to be in air airborn then pressure ease of being there \& the fun my body at my service relaxing my body floating down again into water swimming the pleasure then the waves building carrying more wind which inflates, pushes me up gives me velocity so I begin to circumnavigate in flight over the lake arthur watching perhaps warning I'm saying "it's ok it's fun" then steer myself in slow pressured circles back to water dipping in but instead of entering another wave lifting me pumping air so I am puffed higher, \& each time I try to descend to get back to the water the waves grow larger oceanic like at Asbury with my sister full of spray or like bunkers carring a round cargo pushing me up like those air-puffers you use in a fireplace \& I go higher higher until I am 
seeing nana's bay from a great height circling around like a bird my arms out in front in a V trying to aim down to water again, shouting to arthur "I don't know if I can get back down now I may be too high" \& waves keep pushing me skyward keeping me here not panicky but aware of the dilemma of not being able to control all these elements of being in a new element, which I am equipped for (I know it seems, how to fly) but perhaps not why I should be flying as opposed to swimming that the view is altered and advantageous but also involves a loss of the water's realm \& arthur down there on the shore yelling "come back to earth margaret" so distant \& not even entering the lake

So Feminist Refusals and Revisions on the Romantic Poet's Quest for Self-Possession without Tossing Out the Baby with the Bathwater. To find a voice that says "It wasn't," or differently, "I like my dreams very much, so why don't you push aside to your own" is a kind of perspicacity I know my girlhood used to speak. Within the anaesthesia of adolescence, though my desperation of self-declare took poetic license from subterfuge Romanticist conventions, and I wrote myself as an unintelligible heroine out of the dilemma that as a woman I was both decapitated in language and required to be mellifluous for the protocol of feminine Beauty. "You're a knockout," they would say. But I was colonized by internalized codes about duty, and so to disembowel the oppressiveness of Romanticism from poetry and still write seemed like a face-off that would lead me to silence. My re-awakening happens in language repeatedly, as I feel the structures of exclusion cold under my cheek and commit to turn the other one. Every time I push myself up from the mat, refuse to fight in the binary grammar of dominance, I learn a new aspect of perspicacity. This inclusiveness is a postmodern syntax and a remembering body, with Mrs Pontellier's polyvalent possibility soaring well above the waves, wakefully. It is the critical moment. I won't come back to earth, will you?

\section{Notes}

1. Michelle Cliff, "If I Could Write This In Fire I Would Write This in Fire," Home Girls: A Black Feminist Anthology ed. Barbara Smith (New York: Kitchen Table - Women of Colour Press, 1983.)

2. Gail Scott, Spaces Like Stairs (Toronto: Women's Press, 1989), 110.

3. Marlon Ross, Romantic Quest and Conquest: Troping Masculine Power in the Crisis of Poetic Identity." Romanticism and Feminism, ed. Anne K. Mellor (Bloomington: Indiana University Press, 1988), 32. 


\section{$54 \cdot$ Tessera}

4. Alan Richardson, "Romanticism and the Colonization of the Feminine," in Romanticism and Feminism, 13.

5. Ibid., 17.

6. Ibid., 21.

7. Ibid., 17.

8. Margaret Christakos, "Superstar," excerpted from manuscript-in-progress, "Other Words For Grace," 1991.

9. Erin Mouré, "Watching the Watchwords," Books in Cananda, November 1989, 3-4.

10. Leonard Cohen, Parasites of Heaven (Toronto: McClelland and Steward, 1966), 70 .

11. Nicole Brossard, "Hologram of Desire," translated by Lucille Nelson, Trivia 13, Fall 1988, 42.

12. Kate Chopin, The Awakening (London: The Women's Press, 1978), 25.

13. Ibid., 25.

14. Ibid., 189.

15. Nicole Brossard, These Our Mothers, Or: The Disintegrating Chapter (Toronto: Coach House Press, 1983), translated by Barbara Godard. Originally published in French as l'Amer (Montreal: Les Editions Quinze, 1977).

16. Lou Robinson, “Our Litanies/Our Transfusions," Trivia 13, Fall 1988, 34. [Review of Gail Scott's novel Heroine.]

17. Nicole Brossard, translated by Alice Parker, in "Corps d'enérgie / Rituels d'écriture." Public, 3: 1989, 9.

18. Margaret Christakos, from "Superstar."

19. Lou Robinson, 36.

20. Firewords, (Les Terribles Vivantes: Louky Bersianik, Jovette Marchessault, Nicole Brossard) National Film Board, 1986. English subtitles by Susanne de Lotbiniere-Harwood.

21. Gail Scott, Spaces Like Stairs, 108.

22. Gilligan, Carol, Nona P. Lyons, and Trudy J. Hanmer, eds., Making Connections: The Relational Worlds of Adolescent Girls at Emma Willard School (Cambridge, Mass.: Harvard University Press, 1990).

23. Marlon B. Ross, "Romantic Quest and Conquest: Troping Masculine Power in the Crisis of Male Identity," 34.

24. Sidonie Smith, A Poetics of Women's Autobiography (Bloomington: Indiana University Press, 1987), 9.

25. Brosard, Public, 10.

26. Nancy Chater, bodies of knowledge: fear (Charlottetown, PEI: gynergy, 1989), 36.

27. Erin Mouré, Furious (Toronto: House of Anansi Press, 1988), 37.

28. Nicole Brossard, "Memory: Hologram of Desire," 47. 